\title{
MULTIPLE BIFID RIBS: A CASE REPORT
}

Dhana Lakshmi V ${ }^{1}$, Arun Kumar K. R², Satish Kumar S ${ }^{3}$, Suresh Kumar T4, Suba Ananthi K5

\section{HOW TO CITE THIS ARTICLE:}

Dhana Lakshmi V, Arun Kumar K. R, Satish Kumar S, Suresh Kumar T, Suba Ananthi K. "Multiple Bifid Ribs: A Case Report". Journal of Evolution of Medical and Dental Sciences 2014; Vol. 3, Issue 15, April 14;

Page: 3883-3886, DOI: $10.14260 /$ jemds/2014/2371

ABSTRACT: Ribs are twelve pairs of elastic arches which articulate with vertebral column posteriorly and sternum anteriorly forming much of thoracic skeleton which protects the vital organs. Variations of ribs are being reported and this case report is of multiple bifid ribs observed in a male cadaver. Bifidity occurred in right $2^{\text {nd }}, 4^{\text {th }}$ ribs and in left $3^{\text {rd }}$ rib. Dimensions of the foramina were measured and its way of fusion with sternum through costal cartilages were observed. Multiple bifid ribs are a rare anomaly with the incidence of $0.15 \%$ to $3.4 \%$. Bifid rib can be a feature of Gorlin - Goltz syndrome. Its clinical importance to physicians, surgeons and radiologists were emphasized.

KEYWORDS: bifid ribs, costal cartilage, sternum.

INTRODUCTION: Ribs are twelve pairs of elastic arches which articulate with vertebral column posteriorly and sternum anteriorly forming greater part of thoracic skeleton. The first seven pairs are connected to the sternum by costal cartilages and are referred as true ribs. The remaining five are false ribs; the cartilages of eighth to tenth usually join the superjacent costal cartilage whereas eleventh and twelfth ribs are free at the anterior ends ${ }^{1}$. Anomalies of the ribs such as congenital absence of ribs with costal cartilages, increase or decrease in their number, synostoses between any two ribs from first to tenth or any of the first seven ribs can be bifid ${ }^{2}$. Bifid rib is also called as forked rib.

MATERIALS AND METHODS: During routine dissection of thoracic cage of a male cadaver in the Institute of Anatomy, Madras Medical College, bifidity of multiple ribs were observed. The dimensions of the foramen formed due to the bifidity and the distance of bifurcated ribs from the sternum and the mode of its union with sternum were measured using digital vernier caliper and photographed.

RESULTS: Bifidity was observed in right $2^{\text {nd }}$ rib, $4^{\text {th }}$ rib and left $3^{\text {rd }}$ rib [Fig: 1 ]. Right $2^{\text {nd }}$ and $4^{\text {th }}$ ribs were expanded and bifurcated at a distance of $52.93 \mathrm{~mm}$ and $93.07 \mathrm{~mm}$ respectively from mid sternum. The osseous ends of the bifurcated ribs had its own costal cartilages which then fused to form a trunk and then articulated with sternum.

The left $3^{\text {rd }}$ rib expanded and bifurcated $40.48 \mathrm{~mm}$ from mid sternum but the upper and lower osseous ends articulated with sternum through separate costal cartilages. The dimensions of the foramen were tabulated (Table 1).

Narrowing of right first intercostal space with a difference of $6.19 \mathrm{~mm}$ from the other side was observed because of the bifidity. Similarly right $3^{\text {rd }}$ space and $4^{\text {th }}$ space were narrow with difference of $14.02 \mathrm{~mm}$ and $6.28 \mathrm{~mm}$ respectively from left side. Left $2^{\text {nd }}$ intercostal space was narrowed and the difference between the two sides was $5.61 \mathrm{~mm}$. Intercostal muscles, vessels and nerves were found to be normal. 
DISCUSSION: Ribs develop by endochondral ossification from tips of lateral mesenchymal condensations called costal process in the thoracic region. On $35^{\text {th }}$ day ribs begin to lengthen. By $45^{\text {th }}$ day, first seven ribs are connected ventrally to sternum through costal cartilages. Primary ossification centres appear near the angle of each rib in the sixth week and further ossification occurs in a distal direction. Secondary ossification centres develop in the tubercles and heads of the ribs during adolescence. ${ }^{3}$

Bifid rib or bifurcated rib or forked rib is an anatomical variant where the sternal end of the rib is cleaved into two. Bifid ribs can be unilateral or bilateral. Incidence of bifid rib ranges from $0.15 \%$ to $3.4 \%$ and it accounts for upto $20 \%$ of all congenital rib anomalies. ${ }^{4}$

Bifid ribs are more common in males than females, and occur most frequently in third and fourth ribs (Incidence: third $=$ fourth $>$ fifth $>$ sixth $>$ second). They are slightly more common on right side than on the left. 5

In 2001 M. L. Fily et al reported bifid rib in a man buried around 3400 B.C6. Wattanasirichaigoon et al in 2003 described various patterns of rib defects in 47 cases with bifid rib accounting for $28 \%$ of cases. ${ }^{7}$ Oostra RJ et al in 2006 reported a case with multiple bifid ribs, interpedicular fusion and malsegmentation of vertebral laminae at various upper thoracic levels in a skeleton of a newborn infant. ${ }^{8}$ al- Anazy Fh et al reported a case of bifid rib presented along with calcified falx cerebri and a cystic mass occupying left maxillary sinus protruding into nasal cavity. ${ }^{9}$ As a structural abnormality bifid rib is usually asymptomatic. But may present as a lump in anterior chest wall.10

Anomalies of ribs may represent as an early indicator of other systemic diseases. It can be a feature of Gorlin - Goltz syndrome, a multisystem disorder that manifest with multiple Nevoid basal cell carcinoma, jaw cysts, congenital skeletal abnormalities such as bifid, splayed or synostotic ribs. ${ }^{11}$

Bifid rib is considered as one of the major criteria for Gorlin syndrome ${ }^{12}$. It is caused by mutations in the PTCH1 gene mapped on chromosome 9q22.3. PTCH1 protein is a Hedgehog (Hh) protein receptor and is pivitol for early development, stem cell maintenance and differentiation. ${ }^{13}$ Bifid fourth rib was reported in a case of Kindler syndrome, a rare genodermatosis characterized by acral bullae and photosensitivity. ${ }^{14}$

Bifid rib should be differentiated from other pathological conditions like parenchymal lung lesions in chest radiograph. 3-Dimensional computed tomography is highly effective in differentiating bifid rib from other lesions. ${ }^{15}$

Normally counting of ribs is done from second costal cartilage at sternal angle. As the upper and lower osseous ends of the left $3^{\text {rd }}$ rib in the present case articulated with sternum separately, it may mislead in counting the ribs. Multiple bifid ribs which is rare, is reported for its association with many syndromes and its significance to physicians, cardiothoracic surgeons and radiologists.

\section{REFERENCES:}

1. S. Standring. Gray's Anatomy, 39th edition. Chapter 57, Chest Wall, pp-955, Elsevier, Spain, 2005.

2. W. H. Hollinshead. Anatomy for Surgeons, $2^{\text {nd }}$ edition. The Thorax in General, vol.2, pp-3-5, Harper and Row, publishers, New York, 1971

3. W. J. Larsen. Human Embryology, 3rd edition. Chapter 4, The Fourth week, pp-82-85, Churchill Livingstone, Philadelphia, 2001. 


\section{CASE REPORT}

4. E. Kupeli, G. Ulubay. Bony Bridge of a bifid rib. Cleveland Clinic Journal of Medicine, vol 77, pp. 4232-233, 2010.

5. W.C. Song, S.H. Kim, D.K.Park, K.S. Koh. Bifid Rib: Anatomical Considerations in Three Cases. Yonsei Med J, vol.50 (2) pp.300-303, April 30, 2009.

6. M. L. Fily, E. Crubezy, B. Ludes, D. Rouge et B, Midant-Reynes. Sternal perforation and bifid ribs A possible familial case 5400 years old, an example of epigenetic control of development? Bulletins et memoires de la, Societe d' Anthropologie de, Paris, Numero 13 (1-2) 2001.

7. Wattanasirichaigoon D, Prasad C, Schneider G, Evans JA, Korf BR. Rib defects in patterns of multiple malformations: a retrospective review and phenotypic analysis of 47 cases. Am J Med Genet A 122 A, no.1, , pp. 63-9, Sep 15, 2003.

8. Oostra RJ, Maas M. Bifid ribs and unusual vertebral anomalies diagnosed in an anatomical specimen. Gorlin syndrome? AM J Med Genet A, vol. 140, no. 19, pp.2135-8, Oct 2006.

9. al- Anazy FH, Zakzouk SM. Otolaryngological manifestation of Gorlin Goltz syndrome. J Laryngol Otol.vol.111, no.3, pp.286-9, Mar 1997,

10. S. Scheepers, S. Andronikou. Beware the bifid rib! South African Journal of Radiology, vol 14, no. 4, 2010.

11. D. Batra. Bifid fifth rib in a 9-year old girl with chest pain. Journal of the American Osteopathic Association vol.106, no.6, pp.359-360, June 1, 2006.

12. J. A. Geel, K. G. Bennett, J. M. Rigby, J. E. Poole. Gorlin syndrome. SA Journal of Child Health, vol 5, no.1, pp.21-22, Mar, 2011.

13. C. Takahashi, N. Kanazawa, Y. Yoshikawa, R. Yoshikawa, Y. Saitoh, H. Chiyo, Tanizawa, T.H. Tamaoki and Y. Nakano. Germline PTCH1 mutations in Japanese basal cell nevus syndrome patients. Journal of Human Genetics, vol.54, pp.403-408, July, 2009.

14. Sharma RC, Mahajan V, Sharma NL, Sharma AK. Kindler syndrome. Int J Dermatol, vol.42, no.9, pp. 727-32, Sep 2003.

15. H. Kara, K. Agladioglu, M. Bulut et al. Bifid Rib; Report of Two cases and the Efficacy of 3Dimensional computed Tomography. Journal of Clinical and Analytical Medicine, vol 1, no.2, pp.31-33, 2010.

\begin{tabular}{|c|c|c|c|}
\hline Side & Rib & Transverse(mm) & Vertical(mm) \\
\hline Right & $2^{\text {nd }}$ & 24.59 & 13.97 \\
\hline Right & $4^{\text {th }}$ & 49.33 & 18.15 \\
\hline Left & $3^{\text {rd }}$ & 22 & 8.39 \\
\hline
\end{tabular}

Table 1: The dimensions of the foramen formed by bifid rib 


\section{CASE REPORT}

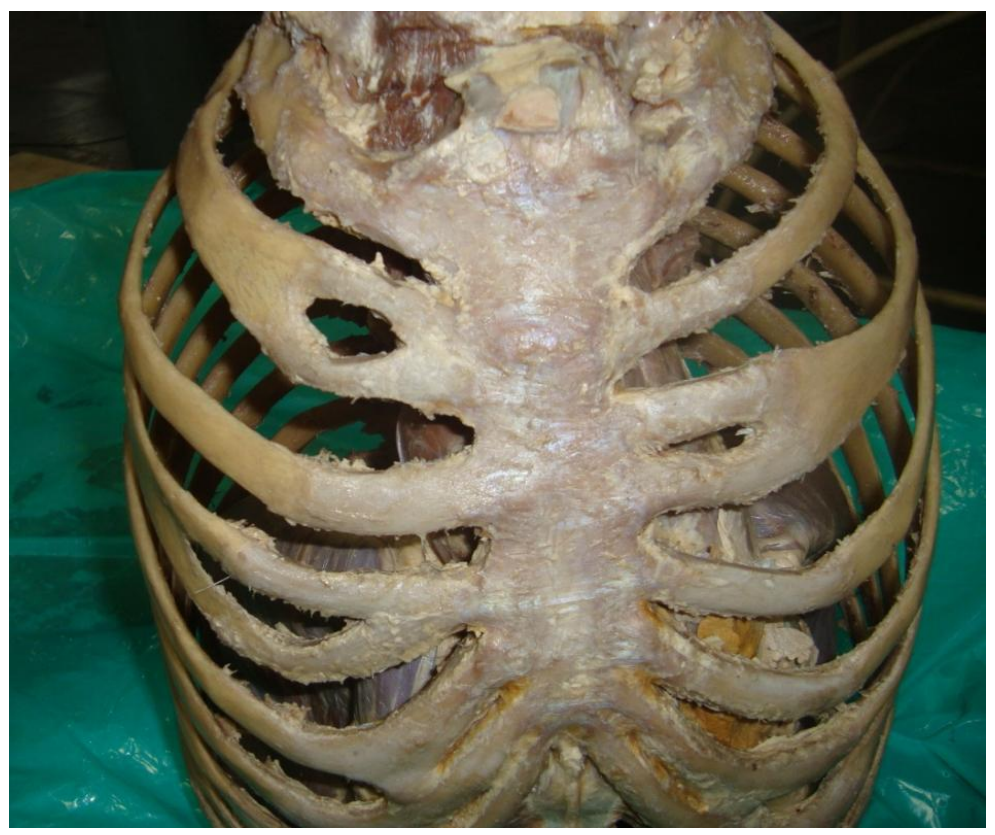

Figure 1: Thoracic cage showing

bifidity in right $2^{\text {nd }}, 4^{\text {th }}$ ribs and in left $3^{\text {rd }}$ rib

\section{AUTHORS:}

1. Dhana Lakshmi V.

2. Arun Kumar K. R.

3. Satish Kumar S.

4. Suresh Kumar T.

5. Suba Ananthi K.

\section{PARTICULARS OF CONTRIBUTORS:}

1. Assistant Professor, Department of Anatomy, Thoothukudi Medical College, Thoothukudi, Tamilnadu.

2. Assistant Professor, Department of Anatomy, Dhanalakshmi Srinivasan Medical College, Perambalur, Tamilnadu.

3. Assistant Professor, Department of Anatomy, Government Mohan Kumaramangalam Medical College, Salem, Tamilnadu.

4. Assistant Professor, Department of Anatomy, Vellore Medical College, Vellore, Tamilnadu.
5. Associate Professor, Department of Anatomy, Indira Gandhi Medical College \& Research Institute, Puducherry, India.

\section{NAME ADDRESS EMAIL ID OF THE CORRESPONDING AUTHOR:}

Dr. Dhana Lakshmi V, Assistant Professor, Department of Anatomy, Thoothukudi Medical College, Thoothukudi, Tamilnadu, India.

E-mail: drlakshmidhana@gmail.com

Date of Submission: 12/03/2014.

Date of Peer Review: 13/03/2014.

Date of Acceptance: 22/03/2014.

Date of Publishing: 08/04/2014. 